\title{
Biodiversity and ecology of meiofauna in extreme and changing environments
}

\author{
Daniela Zeppilli ${ }^{1} \cdot$ Daniel Leduc $^{2}$ \\ Published online: 11 January 2018 \\ (C) Senckenberg Gesellschaft für Naturforschung and Springer-Verlag GmbH Germany, part of Springer Nature 2018
}

Meiofauna (small interstitial animals and protists living in aquatic sediments) are ubiquitous. Owing to their high abundance and diversity, widespread distribution, rapid generation times and fast metabolic rates, meiofaunal organisms are important contributors to ecosystem processes and functions, including nutrient cycling and provision of food to higher trophic levels, among others (Woodward 2010; Schratzberger and Ingels 2017). Meiofauna, however, have typically received less attention than the larger and more easily studied macro- and megafauna, and more needs to be done to train the next new generation of meiobenthologists. In order to bridge this gap, the second meiofauna summer school, "MeioScool2016 - a dive in a microscopic world", was held in Brest, France, 27 June -1 July 2016, and attracted 131 scientists and students from 26 countries (Fig. 1; https://meioscool2016.sciencesconf.org/). Like the first summer school held in 2013, the objectives of MeioScool2016 were to bring together meiofaunal experts in several meiofauna-related sub-disciplines from all over the world to: (1) increase awareness of researchers, students and general public to the fundamental role of meiofauna in marine ecosystems from the coastal zone to the deep sea, and (2) train students and researchers in the identification and description of meiofaunal communities through several complementary disciplines (taxonomy, ecology, molecular biology). The first 2 days were devoted to oral and poster presentations by invited speakers, researchers, and students, while the three other days consisted of practical workshops and field and laboratory work. Two sessions of

Daniela Zeppilli

Daniela.Zeppilli@ifremer.fr

1 IFREMER, Centre Brest, REM/EEP/LEP, Institut Carnot Ifremer-EDROME, ZI de la pointe du diable, CS10070, 29280 Plouzané, France

2 National Institute of Water and Atmospheric Research, Private Bag 14-901, Wellington 6021, New Zealand this summer school were devoted to the meiofauna of extreme and changing environments: "Session 4: Deep-sea and extreme meiofauna" and "Session 5: Meiofauna response to anthropogenic impacts".

Extreme environments (i.e., environments characterised by one or more environmental parameters permanently close to the lower or upper limits for life; CAREX 2011) cover more than 50\% of the Earth's surface (Zeppilli et al. 2017), and offer many opportunities for investigating the biological responses and adaptations of organisms to stressful life conditions (Rothschild and Mancinelli 2001). The fauna adapted to extreme environments may be particularly sensitive to environmental changes (Catalan et al. 2006; Bellard et al. 2012) and can be used as biological indicators of pollution and global change (Zeppilli et al. 2015). Among the communities present in extreme natural environments, we constantly find meiofauna organisms. This Special Issue of Marine Biodiversity comprises studies and reviews related to extreme environments including taxonomy of extreme meiofauna, and biodiversity and ecology of meiofauna in extreme or changing environments (Table 1).

The first contribution to this Special Issue provides a description of a new marine arthrotardigrade species (GomesJúnior et al. 2017). Ligiarctus alatus sp. nov. was discovered in sediments of the Brazilian continental shelf in the Southwestern Atlantic Ocean, from sites located in the major oil extraction basins in Brazil (Campos and Potiguar basins). The review of Rosli et al. (2017) describes trends in the ecology of deep-sea meiofauna with focus on patterns and processes at small to regional spatial scales described in studies published since the last review of deep-sea meiofauna of Soltwedel (2000), and highlights areas needing further research. Zeppilli et al. (2017) present an integrated review of the biodiversity, ecology and physiological responses of marine meiofauna inhabiting extreme marine environments, including mangroves, submarine caves, polar ecosystems, hypersaline areas, hypoxic/anoxic environments, hydrothermal vents, cold seeps, carcasses/sunken woods, deep-sea canyons, 
Fig. 1 Group photograph of onsite participants of the MeioScool2016 Summer School

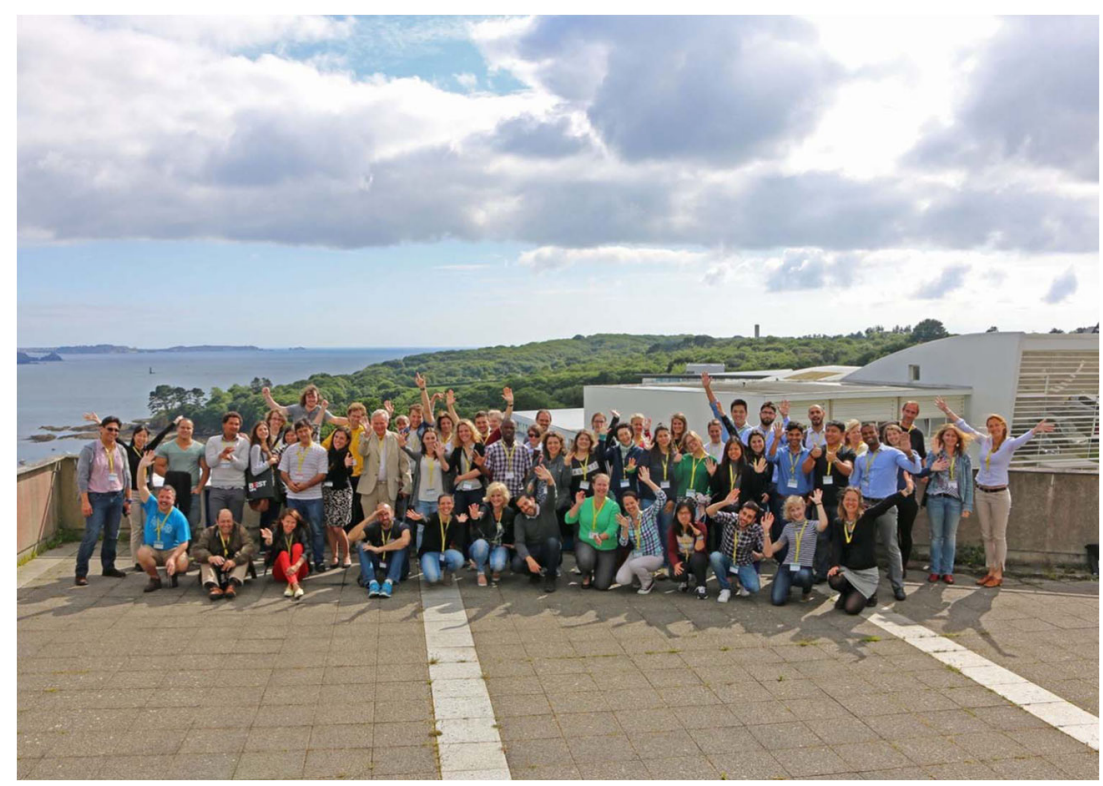

deep hypersaline anoxic basins and hadal zones. Singh et al. (2017) present a study of the vertical distribution of living benthic foraminiferans from the oxygen minimum zone of the Gulf of Mannar, Southeastern Arabian Sea, which shows how oxygen concentrations impact vertical benthic living foraminiferal distribution. A pilot deep-sea colonisation experiment on the Lucky Strike vent field (Mid-Atlantic Ridge) by Baldrighi et al. (2017) shows that the complex structure of inorganic sponge substrata may favour settlement of juveniles and larvae, and may provide a useful sampling

Table 1 List of papers presented in this Special Issue of Marine Biodiversity

\begin{tabular}{|c|c|c|c|c|}
\hline Reference & Topic & Taxon & Geographic area & Ecosystem \\
\hline Baldrighi et al. (2017) & $\begin{array}{l}\text { Ecology and biodiversity } \\
\text { of meiofauna in extreme } \\
\text { environments }\end{array}$ & $\begin{array}{c}\text { Meiofauna and } \\
\text { Macrofauna }\end{array}$ & $\begin{array}{l}\text { Lucky Strike, Mid Atlantic } \\
\text { Ridge, Atlantic Ocean }\end{array}$ & Deep sea \\
\hline Chen et al. (2017) & $\begin{array}{l}\text { Ecology and biodiversity } \\
\text { of meiofauna in changing } \\
\text { environments }\end{array}$ & Nematodes & Malaysia & Polluted area \\
\hline $\begin{array}{l}\text { Gomes-Júnior et al. } \\
\text { (2017) }\end{array}$ & $\begin{array}{l}\text { Taxonomy of meiofauna } \\
\text { in extreme and changing } \\
\text { environments }\end{array}$ & Tardigrada & $\begin{array}{l}\text { Brazilian Continental } \\
\text { Shelf, Southwestern } \\
\text { Atlantic Ocean }\end{array}$ & Oil and gas impact area \\
\hline Polese et al. (2017) & $\begin{array}{l}\text { Ecology and biodiversity } \\
\text { of meiofauna in changing } \\
\text { environments }\end{array}$ & Meiofauna & $\begin{array}{l}\text { Thyrrenian Sea, } \\
\text { Mediterranean Sea }\end{array}$ & Polluted area \\
\hline Quang et al. (2017) & $\begin{array}{l}\text { Ecology and biodiversity } \\
\text { of meiofauna in changing } \\
\text { environments }\end{array}$ & Nematodes & $\begin{array}{l}\text { Sai Gon River harbours, } \\
\text { Vietnam }\end{array}$ & Polluted area \\
\hline Rosli et al. (2017) & $\begin{array}{l}\text { Ecology and biodiversity } \\
\text { of meiofauna in extreme } \\
\text { environments }\end{array}$ & Meiofauna & Worldwide & Deep sea \\
\hline $\begin{array}{l}\text { Semprucci et al. } \\
\text { (2017) }\end{array}$ & $\begin{array}{l}\text { Ecology and biodiversity } \\
\text { of meiofauna in changing } \\
\text { environments }\end{array}$ & $\begin{array}{l}\text { Meiofauna and } \\
\text { Nematodes }\end{array}$ & $\begin{array}{l}\text { Adriatic Sea, } \\
\text { Mediterranean Sea }\end{array}$ & Polluted area \\
\hline Singh et al. (2017) & $\begin{array}{l}\text { Ecology and biodiversity } \\
\text { of meiofauna in extreme } \\
\text { environments }\end{array}$ & Foraminifera & $\begin{array}{l}\text { South-Eastern } \\
\text { Arabian Sea }\end{array}$ & Deep sea and Oxygen Minimum Zone \\
\hline Zeppilli et al. (2017) & $\begin{array}{l}\text { Ecology and biodiversity } \\
\text { of meiofauna in extreme } \\
\text { environments }\end{array}$ & Meiofauna & Worldwide & $\begin{array}{l}\text { Mangroves, submarine caves, Polar ecosystems, } \\
\text { hypersaline areas, hypoxic/anoxic environments, } \\
\text { hydrothermal vents, cold seeps, carcasses/sunken } \\
\text { woods, deep-sea canyons, deep hypersaline } \\
\text { anoxic basins and hadal zones }\end{array}$ \\
\hline
\end{tabular}


method for ecological studies. Two studies within this special issue show that meiobenthic and nematode assemblages can be used to determine the ecological quality (EcoQ) of highly impacted areas (Semprucci et al. 2017; Chen et al. 2017). Finally, Polese et al. (2017) describe a study of meiofauna from the Phlegraean archipelago (Southern Italy) comparing pristine (Nisida islet) and highly impacted area (Bagnoli), and Quang et al. (2017) describe the impact of toxic tributyltin (TBT) compounds on free-living nematode communities in the Sai Gon River.

The discovery of abundant and well-adapted meiofaunal communities in several environments with extreme conditions has provided new insights into the ecology and physiology of species thriving in challenging settings (e.g., Danovaro et al. 2010; Fontaneto et al. 2015). As well as natural processes, human activities may generate stressful conditions, including deoxygenation, acidification and rises in temperature. The behaviour and physiology of different meiofaunal taxa, such as some foraminiferans, nematode and copepod species, can provide vital information on how organisms may respond to these challenges and can provide a warning signal of anthropogenic impacts. From an evolutionary perspective, the discovery of new meiofauna taxa from extreme environments often sheds light on phylogenetic relationships, while understanding how meiofaunal organisms are able to survive or even flourish in these conditions can explain evolutionary pathways. Finally, there are multiple potential economic benefits to be gained from ecological, biological, physiological and evolutionary studies of meiofauna in extreme environments. Given the many insights to be gained from studies of meiofauna of extreme and changing environments, there is a clear need to continue research capability in this area through multidisciplinary courses such as Meioscool.

Acknowledgements The authors thank the western France laboratory cluster (Laboratoire d'Excellence) LabexMER (ANR-10-LABX-19), the French Research Institute for the Exploitation of the Sea (IFREMER), the Institut Carnot, the Total Foundation, the University of Western Brittany and the European Institute for Marine Studies for financing the MeioScool2016 project: Meiofaunal Summer School, held in Brest (27 June-1 July 2016). DZ was supported by the project "Prokaryote-nematode Interaction in marine extreme envirONments: a uniquE source for ExploRation of innovative biomedical applications" (PIONEER) funded by the Total Fondation and IFREMER. We thank Pedro Martinez Arbizu, the editor in chief of Marine Biodiversity, for continuous support and encouragement.

Funding This study was funded by the western France laboratory cluster (Laboratoire d'Excellence) LabexMER (ANR-10-LABX-19), the French Research Institute for the Exploitation of the Sea (IFREMER), the Institut Carnot, the TotalFoundation, the University of Western Brittany and the European Institute for Marine Studies and by the project"Prokaryotenematode Interaction in marine extreme envirONments: a uniquE source for ExploRation of innovativebiomedical applications" (PIONEER) funded by the Total Fondation and IFREMER.

\section{Compliance with ethical standards}

Conflict of interest The authors declare that they have no conflict of interest.

Ethical approval This article does not contain any studies with animals performed by any of the authors.

Sampling and field studies All necessary permits for sampling and observational field studies have been obtained by the authors from the competent authorities and are mentioned in the acknowledgements, if applicable.

\section{References}

Baldrighi E, Zeppilli D, Crespin R, Chauvaud P, Pradillon F, Sarrazin J (2017) Colonization of synthetic sponges at the deep-sea Lucky Strike hydrothermal vent field (Mid-Atlantic Ridge): a first insight. Mar Biodiv (this issue)

Bellard C, Bertelsmeier C, Leadley P, Thuiller W, Courchamp F (2012) Impacts of climate change on the future of biodiversity. Ecol Lett 15(4):365-377

Catalan J, Camarero L, Felip M, Pla S, Ventura M, Buchaca T, Bartumeus F, Mendoza GD, Miró A, Casamayor EO, Medina-Sánchez JM (2006) High mountain lakes: extreme habitats and witnesses of environmental changes. Limnetica 25(1-2):551-584

CAREX (2011) CAREX roadmap for research on life in extreme environment. CAREX Project Office, Strasbourg $48 \mathrm{pp}$

Chen CA, Soo CL, Balsamo M, Semprucci F (2017) An approach based on nematode descriptors for the classification of ecological quality (EcoQ) of the Malaysian coasts. Mar Biodiv (this issue)

Danovaro R, Dell'Anno A, Pusceddu A, Gambi C, Heiner I, Kristensen RM (2010) The first metazoa living in permanently anoxic conditions. BMC Biol 8:1-30

Fontaneto D, Iakovenko N, De Smet WH (2015) Diversity gradients of rotifer species richness in Antarctica. Hydrobiol 761(1):235-248

Gomes-Júnior E, Santos E, da Rocha CMC, Santos PJP, Fontoura P (2017) A new species of Ligiarctus (Tardigrada, Arthrotardigrada) from the Brazilian continental shelf, Southwestern Atlantic Ocean. Mar Biodiv (this issue)

Polese G, Semprucci F, Campoli L, Maselli V, d'Alcalà MR, Balsamo M, Di Cosmo A (2017) Meiofaunal assemblages of the bay of Nisida and the environmental status of the Phlegraean area (Naples, Southern Italy). Mar Biodiv (this issue)

Quang NX, Yen NTM, Van Dong N, Prozorova L, Smol N, Lins L, Vanreusel A (2017) Nematode communities in the Sai Gon River harbors in relation to tributyltin concentrations. Mar Biodiv (this issue)

Rosli N, Leduc D, Rowden AA, Probert PK (2017) Review of recent trends in ecological studies of deep-sea meiofauna, with focus on patterns and processes at small to regional spatial scales. Mar Biodiv (this issue)

Rothschild LJ, Mancinelli RL (2001) Life in extreme environments. Nature 409:1092-1101

Schratzberger M, Ingels J (2017) Meiofauna matters: the roles of meiofauna in benthic ecosystems. J Exp Mar Biol Ecol. In press

Semprucci F, Balsamo M, Appolloni L, Sandulli R (2017) Assessment of ecological quality status along the Apulian coasts (eastern Mediterranean Sea) based on meiobenthic and nematode assemblages. Mar Biodiv (this issue)

Singh DP, Saraswat R, Kaithwar A (2017) Changes in standing stock and vertical distribution of benthic foraminifera along a depth gradient 
$(58-2750 \mathrm{~m})$ in the southeastern Arabian Sea.. Mar Biodiv (this issue)

Soltwedel T (2000) Metazoan meiobenthos along continental margins: a review. Prog Oceanogr 46:59-84

Woodward G (2010) Integrative ecology, volume 43: from molecules to ecosystems. Advances in ecological research. Academic Press, London

Zeppilli D, Sarrazin J, Leduc D, Arbizu PM, Fontaneto D, Fontanier C, Gooday AJ, Kristensen RM, Ivanenko VN, Sørensen MV, Vanreusel A, Thébault J, Mea M, Allio N, Andro T, Arvigo A, Castrec J, Danielo M, Foulon V, Fumeron R, Hermabessiere L, Hulot V, James T, Langonne-Augen R, Le Bot T, Long M, Mahabror D,
Morel Q, Pantalos M, Pouplard E, Raimondeau L, Rio-Cabello A, Seite S, Traisnel G, Urvoy K, Van Der Stegen T, Weyand M, Fernandes D (2015) Is the meiofauna a good indicator for climate change and anthropogenic impacts? Mar Biodivers 45:505-535

Zeppilli D, Leduc D, Fontanier C, Fontaneto D, Fuchs S, Gooday AJ, Goineau A, Ingels J, Ivanenko VN, Kristensen RM, Neves RC, Sanchez N, Sandulli R, Sarrazin J, Sørensen MV, Tasiemski A, Vanreusel A, Autret M, Bourdonnay L, Claireaux M, Coquillé V, De Wever L, Rachel D, Marchant J, Toomey L, Fernandes D (2017) Characteristics of meiofauna in extreme marine ecosystems: a review. Mar Biodiv (this issue) 